\title{
Monolayer Culture of Neonatal Pig Pancreatic Islet Cells
}

\author{
F.J.Archer \\ Department of Pediatrics, Hahnemann Medical College and Hospital, Philadelphia, Pennsylvania, USA
}

\begin{abstract}
Summary. Pancreatic islet cells from pigs (3-12 days old) were maintained in monolayer culture at $37^{\circ} \mathrm{C}$ for $>30$ days. Cultures were maintained in enriched Medium 199 with $5 \%$ fetal calf serum and with the glucose concentration being cycled between 11.10 and $27.75 \mathrm{mmol} / 1$ every 2 days. The presence of $B$ cells in the cultures was demonstrated by insulin secretion into the culture medium, cell staining with aldehyde fuchsin and immunofluorescence. A cells in the cultures were monitored by glucagon secretion into the medium. The absence of exocrine cells was determined by the inability to detect $\alpha$-amylase in the culture medium. Insulin secretion determined over a 34-day period, was found to diminish after 12 days in culture. The fall in levels of extractable B cell insu-
\end{abstract}

lin with time correlated with the levels of insulin secreted into the medium. Response to short term glucose stimulation ( $2 \mathrm{~h}$ in serum-free medium) was determined on days 6,10 and 12 in culture. Morphological changes appeared after 25 days in culture, although on day 33 insulin secretion was $62.5 \mu \mathrm{U}$. culture $^{-1}$. day ${ }^{-1}$. DNA synthesis (determined by ${ }^{3} \mathrm{H}$-thymidine incorporation and autoradiography) was demonstrated (day 12, 39.4 \pm 0.9 labelled cells/culture). These findings suggest that pig islet cell monolayer cultures are a useful tool for morphological and biochemical studies and that neonatal pig islets are a potential source of material for transplantation.

Key words: Pig islets, B cells, monolayers, insulin.
Isografted isolated pancreatic islets can effectively reverse experimental diabetes in rodent models $[1,2]$. The successful transplantation of cultured islets across strong histocompatibility barriers in rodents has also been reported [2-5]. Unfortunately, similar studies in larger animals have been few and the results generally poor $[2,6-8]$. Very limited beneficial effects have been reported with human islets in auto and allo transplantation [9]. Limiting the effectiveness of human and large animal studies has been the unavailability of suitable tissue for islet preparation, and the poor yield of islet cells from adult man, dog and monkey tissues $[10,11]$. Pig pancreas, a fibrous and compact organ similar to the human pancreas, is readily available. Neonatal pig pancreas could be a potential source of islets for human xenografts and therefore was chosen for study.

Islets were isolated from 3-12 day old pig pancreas and maintained in monolayer culture by techniques described below. The response of cells to glucose was determined by changes in insulin secretion into the culture medium. Growth potential was evaluated by ${ }^{3} \mathrm{H}$-thymidine incorporation.

\section{Materials and Methods}

Collagenase $(136 \mathrm{U} / \mathrm{mg}) \mathrm{Cl}$. histolyticum was obtained from Grand Island Biological Company, New York, USA. Dispase neutral protease (bacillus polymyxa) Grade II was supplied by Boehringer Mannheim, FRG. Culture medium 199, Hanks balanced salt solution, fetal calf serum, D-glucose, Na pyruvate, L-glutamine, penicillin/ streptomycin and tissue culture plates were also obtained from Grand Island Biological Company, New York. D-valine, cis-4-OH-proline and collagen (calf-skin, acid soluble) were supplied by Calbiochem, San Diego, California, USA. Selenium, copper and zinc salts were obtained from Sigma Chemicals, St. Louis, Missouri, USA. Vitamin B $_{12}$, L-ascorbic acid, dl- $\alpha$-tocopherol and transferrin were supplied by ICN-Nutritional Biochemicals, Ohio, USA. Putrescine and porcine insulin were purchased from Collaborative Research, Waltham, Massachusetts, USA. ${ }^{3} \mathrm{H}$-thymidine $(20 \mathrm{Ci} / \mathrm{mmol}),{ }^{125} \mathrm{I}$-insulin, antibodies and standards were purchased from Amersham International, Bucks, $\mathrm{UK}$, and ${ }^{125}$ I-glucagon, antibodies and standards from Cambridge Nuclear, Billerica, Massachusetts, USA. NTB nuclear track emulsion, developer and fixer were obtained from Eastman Kodak, Rochester, New York, USA. Guinea pig anti-bovine insulin and rhodaminated goat anti-guinea pig IgG were purchased from Cappel Laboratories, Cochranville, Pennsylvania, USA. Mouse liver acetone powder was obtained from Sylvania, Milburn, New Jersey, USA. Amylase test kits were purchased from Pharmacia, Uppsala, Sweden. All other chemicals were purchased from Fisher Scientific, King of Prussia, Pennsyl- 
vania, USA. Neonatal pigs were obtained from McHarg Pig Farms, West Chester, Pennsylvania, USA.

\section{Media}

Pancreas dissection and washing were carried out in Medium 199 containing $2 \%$ heat inactivated fetal calf serum, streptomycin sulphate $(0.1 \mathrm{~g} / \mathrm{l})$ and penicillin $\mathrm{G}$ potassium $(0.1 \mathrm{~g} / \mathrm{l}), \mathrm{pH}$ adjusted to 7.4 with $\mathrm{NaHCO}_{3}$. Cells were cultured in Medium 199 containing $5 \%$ fetal calf serum, $\mathrm{NaHCO}_{3}(8 \mathrm{mmol} / \mathrm{l})$ glutamine $(5 \mathrm{mmol} / \mathrm{l}) \mathrm{Na}$ pyruvate $(1 \mathrm{mmol} / \mathrm{l})$, glucose $(11.10 \mathrm{mmol} / \mathrm{l})$, transferrin $(5 \mathrm{ng} / \mathrm{ml})$, ascorbic acid $(50 \mathrm{mg} / \mathrm{ml})$, tocopherol $(0.5 \mathrm{ng} / \mathrm{ml})$, Vitamin $\mathrm{B}_{12,},\left(1 \times 10^{-6}\right.$ $\mathrm{mol} / \mathrm{l}) \mathrm{ZnSO}_{4} \cdot \mathrm{H}_{2} \mathrm{O},\left(3 \times 10^{-8} \mathrm{~mol} / \mathrm{l}\right) \mathrm{CuSO}_{4} 5 \mathrm{H}_{2} \mathrm{O}\left(1 \times 10^{-8} \mathrm{~mol} / \mathrm{l}\right)$ and selenium $\left(3 \times 10^{-6} \mathrm{~g} / \mathrm{l}\right)$. Glucose stimulation studies were performed in the same medium, without serum or glucose. Glucose was added at $5.55,11.10$ and $27.75 \mathrm{mmol} / \mathrm{l}$.

\section{Islet Cell Isolation and Culture}

Pancreases were removed from neonatal pigs under halothane anaesthesia using sterile techniques and immediately placed in ice-cold Medium 199 containing cobalt chloride $(0.5 \mathrm{mg} / \mathrm{ml})$. The organ was washed with three changes of medium and held in medium on ice until processed. The tissue was dissected free of blood vessels, ducts and visible connective tissue under a dissecting microscope. The resulting small pieces of pancreas were further dissected to remove any remaining connective tissue, and then were passed through an $18 \mathrm{G}$ needle and gently sedimented. This material was resuspended in Hanks' balanced salt solution containing collagenase $(2 \mathrm{mg} / \mathrm{ml})$ and incubated with shaking at $37^{\circ} \mathrm{C}$ for $15 \mathrm{~min}$. The supernatant was removed and incubation continued for another 10 min with fresh collagenase solution. This solution was decanted and Hanks's balanced salt solution containing dispase $(1 \mathrm{mg} / \mathrm{ml})$ was added and the incubation continued for an additional $5 \mathrm{~min}$. At the end of this period the supernatant was decanted and fresh medium added to the residue. The residue and all supernatant fractions were centrifuged, washed in media and recentrifuged at low speed, at least four times, to remove residual enzymes and partially digested connective tissue. The gently pelleted islet cell clumps were resuspended in complete Medium 199 with $10 \%$ fetal calf serum and incubated in tissue culture plates for $12 \mathrm{~h} \mathrm{at} 37^{\circ} \mathrm{C}$ in $95 \%$ air $/ 5 \% \mathrm{CO}_{2}$. The unattached cell clumps were removed, gently sedimented, resuspended in fresh Medium 199 with $5 \%$ fetal calf serum, and placed in collagen-coated plates. After 2-3 days in culture, monolayers were treated with proline and hydroxyproline free Medium 199 containing $\mathrm{D}$-valine (100 mg/1) [12], and cis-4-hydroxyproline $(100 \mu \mathrm{g} / \mathrm{ml})$ [13], for $24 \mathrm{~h}$. The culture medium was changed every 2 days. For long-term culture, the glucose content was varied between 11.10 and $27.75 \mathrm{mmol} / \mathrm{l}$ at each medium change. Aliquots were taken every $24 \mathrm{~h}$ and stored at $-20^{\circ} \mathrm{C}$ in the presence of Trasylol (aprotinin). Media samples were analyzed for insulin and glucagon content by radioimmunoassay. Insulin was determined using the Amersham kit which is based on the double-antibody method of Hales and Randle [14], and porcine insulin was used as the standard. The coefficient of variation of this procedure is $<20 \%$. Glucagon was determined by the method of Faloona and Unger [15], using porcine glucagon standards, porcine ${ }^{125} \mathrm{I}$-glucagon and rabbit anti-glucagon antibody (against porcine pancreatic glucagon). The coefficient of variation of this procedure is $<30 \%$. Media samples were assayed also for the the presence of $\alpha$-amylase [16] using the Pharmacia dye conjugated starch kit. The coefficient of variation for this method is $<4 \%$.

The presence of insulin in cells in monolayer culture was determined by histochemical techniques. For these assays, cells were grown on glass coverslips. Insulin-containing granules in pancreatic B cells were detected by a modified aldehyde-fuchsin method [17] Briefly, cells were fixed in Bouin's solution for $6 \mathrm{~h}$; rinsed and oxidized in $5 \% \mathrm{KMnO}_{4}$ in $0.5 \mathrm{~N} \mathrm{H}_{2} \mathrm{SO}_{4}$; washed and stained in aldehyde fuchsin $(0.5 \%$ basic fuchsin in $70 \% \mathrm{EtOH}, 1 \% \mathrm{HCl}$ and $1 \%$ paraldehyde) for $5 \mathrm{~min}$. The stained cells were rinsed in $0.05 \mathrm{~N} \mathrm{HCl}$ in $70 \%$ EtOH and counter-stained in $10 \%$ poncea stain and rinsed in $2 \%$ phosphomolybdic acid. Coverslips were air dried, mounted on glass slides and observed for B cell granules by a phase contrast microscope. In some monolayer cultures, the presence of insulin within B cells was determined by an indirect immunofluorescence assay based on the method of Orci et al. [18]. Briefly, cell monolayers on coverslips were fixed in acetone, washed twice in phosphate buffered saline (PBS) and rinsed in distilled water. Excess water was removed, and the cell monolayer was covered with anti-insulin serum and incubated for $1 \mathrm{~h}$ at $37^{\circ} \mathrm{C}$ in a humidified atmosphere. The cultures were washed $\times 3$ in PBS and once in distilled water, and air dried. Cells were overlayed with rhodaminated anti-guinea pig serum and incubated for $1 \mathrm{~h}$ at $37^{\circ} \mathrm{C}$ in a humidified atmosphere. After thorough rinsing in PBS and distilled water, the cultures were air dried and observed with a Zeiss microscope with an Osram high pressure mercury bulb (HBO $200 \mathrm{~W}$ ) using a $590 \mathrm{~nm}$ barrier filter. Human skin fibroblast cultures on coverslips were used as negative controls.

\section{Glucose Stimulation Studies}

Cells were incubated in serum-free complete Medium 199. One set of cultures $(6 \times 60 \mathrm{~mm}$ plates) was incubated for each time point for $2 \mathrm{~h}$ in medium ( $3 \mathrm{ml}$ ) containing $11.10 \mathrm{mmol} / 1$ glucose. The medium was removed and stored at $-70^{\circ} \mathrm{C}$ and the cultures gently washed with serum and glucose free medium. Fresh medium $(3 \mathrm{ml})$ containing $27.75 \mathrm{mmol} / 1$ glucose was added and the incubation continued for a further $2 \mathrm{~h}$, after which the medium was removed and stored at $-70^{\circ} \mathrm{C}$. In another set of cultures $(6 \times 60 \mathrm{~mm}$ plates for each time point), the first 2 -h incubation was in medium containing $27.75 \mathrm{mmol} / 1$ glucose followed by a $2 \mathrm{~h}$ incubation in medium containing $11.10 \mathrm{mmol} / 1$ glucose. Finally, the monolayers were removed from the culture surface, extracted into $0.1 \mathrm{~N} \mathrm{NaOH}$ and the protein content determined by a micro-modification of the Lowry et al. method [19]. In a further set of cultures, after glucose stimulation, the monolayers were extracted with acid/ethanol $(1.5 \mathrm{ml} 12 \mathrm{~N} \mathrm{HCl}$ in $100 \mathrm{ml} 70 \% \mathrm{EtOH}$ ) for determination of residual cellular insulin. Insulin levels were determined by radioimmunoassay using ${ }^{125} \mathrm{I}$-insulin and porcine insulin standards.

\section{Autoradiography}

DNA synthesis by monolayer cultures was determined by ${ }^{3} \mathrm{H}$-thymidine incorporation followed by autoradiography. Cultures were incubated at $37{ }^{\circ} \mathrm{C}$ for $4 \mathrm{~h}$ with ${ }^{3} \mathrm{H}$-thymidine $(20 \mathrm{Ci} / \mathrm{mmol}, 1.0 \mu \mathrm{Ci} / \mathrm{ml} \mathrm{me}-$ dium) rinsed and fixed in glacial $\mathrm{CH}_{3} \mathrm{COOH} / \mathrm{EtOH}(1: 5)$. The monolayers were coated with photographic emulsion and maintained in the dark at $4{ }^{\circ} \mathrm{C}$ for 3 weeks, then developed and stained with haemotoxylin and eosin. Six plates for each time point and glucose concentration were scored for the percentage of labelled cells counted under a phase contrast microscope. Statistical significance of all experiments was estimated using the two-tailed $t$-test.

\section{Results}

Glucose responsive monolayer cultures of islet cells could be consistently established from 3 to 12-day-old pig pancreases by the methods used. It was found that careful dissection and removal of connective tissue from the pancreas before enzyme digestion resulted in relatively clean preparations. Cultures were prepared from 20 pigs, one pancreas yielding $20-25$ cultures in $60 \mathrm{~mm}$ plates. Pigs ranged in age from 3-12 days and consisted of 8 females and 12 males. The age and sex distribution was as follows: 3 days, four females and five males; 4 days, one female; 5 days, two females and two males; 7 days, one male; 10 days, three males; 

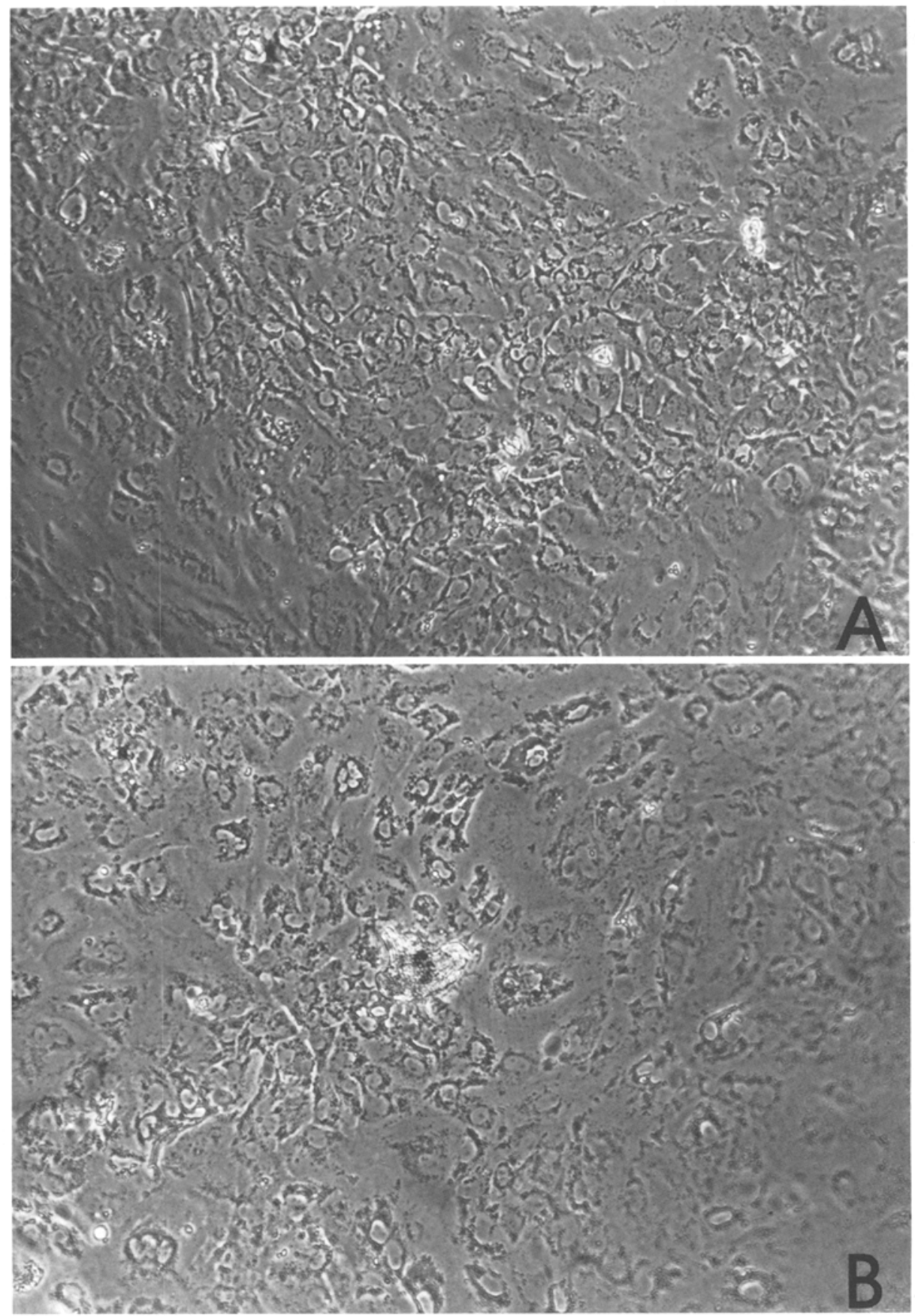

Fig. $1 \mathrm{~A}$ and B. Monolayer pig pancreatic islet cell cultures. Morphology of A cultures after 7 days at $37^{\circ} \mathrm{C} ; \mathbf{B}$ cultures after 23 days at $37^{\circ} \mathrm{C}$. Photomicrographs using phase contrast $(\times 100)$
12 days, one female and one male. Pancreases from the 12-day old animals were found to be much more fibrous than those from the younger animals. Isolated islets were monitored by a phase contrast microscope immediately after enzyme treatment and washing. In the majority of preparations, intact islets with no visible connective tissue or acinar tissue attachments were observed. The use of a 10 -min incubation with dispase after collagenase digestion produced many single cells and small islet cell clumps, but these attached to the culture surface more slowly than cells incubated with collagenase alone. Islets were placed in $60-\mathrm{mm}$ tissue culture plates in medium containing $10 \%$ fetal calf serum and incubated at $37^{\circ} \mathrm{C}$ for $12 \mathrm{~h}$. At the end of this period, unattached islets were removed and transferred to collagen-coated plates and incubated for a further $24 \mathrm{~h}$. Loosely attached islets and cell clumps were removed and plated in fresh collagen-coated plates. All cultures were transferred to complete Medium 199, containing $5 \%$ fetal calf serum. Cells attached and began to spread out on the culture surface in 2-3 days. If fibroblasts became visible (under phase microscope) after the establishment of cultures (2-6 days), their growth could be inhibited by the use of proline-free medium containing cis-4-hydroxyproline or D-valine. In cultures prepared from 16 pancreases, treatments were as follows: cul- 


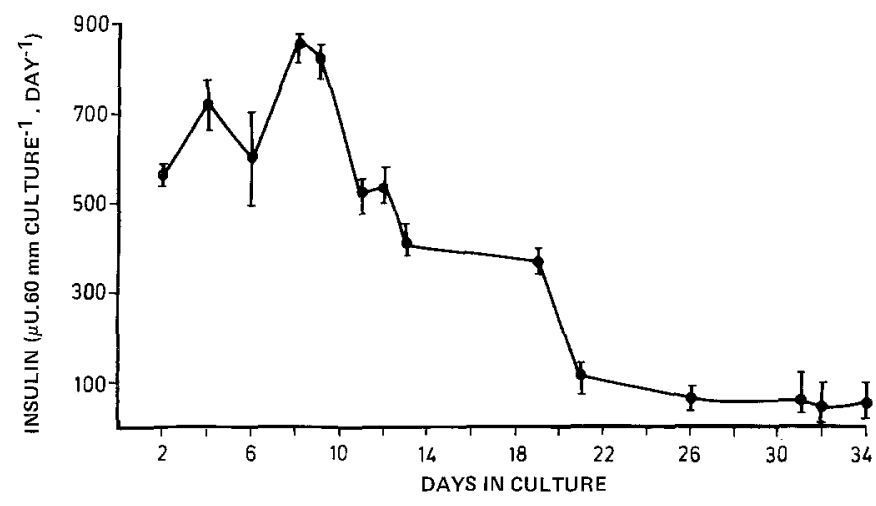

Fig. 2. Monolayer pig pancreatic islet cell cultures. Secretion of insulin over 34 days in culture at $37^{\circ} \mathrm{C}$. Medium glucose levels alternated between 11.10 and $27.75 \mathrm{mmol} / 1$ every 2 days. Each point represents the mean $\pm \mathrm{SD}$ of 12 separate cultures

Table 1. DNA synthesis, ${ }^{3} \mathrm{H}$-thymidine incorporation into islet cell monolayer cultures as shown by autoradiography ( $\%$ labelled cells)

\begin{tabular}{lll}
\hline Cultures & \multicolumn{2}{l}{ Glucose } \\
\cline { 2 - 3 } & $11.10 \mathrm{mmol} / 1$ & $27.75 \mathrm{mmol} / 1$ \\
\hline Day 8 & $39.4 \pm 6.2$ & $46.3 \pm 2.7$ \\
Day 12 & $39.4 \pm 0.9$ & $31.2 \pm 6.5$ \\
\hline
\end{tabular}

Results expressed as mean \pm SD of six cultures

Table 2. Insulin secretion by monolayer cultures of pancreatic islet cells in response to a 2 -h glucose challenge

\begin{tabular}{|c|c|c|c|c|}
\hline \multirow[t]{3}{*}{ Cultures } & \multicolumn{4}{|l|}{ Glucose } \\
\hline & \multicolumn{2}{|l|}{ Experiment $A$} & \multicolumn{2}{|l|}{ Experiment $B$} \\
\hline & $11.10 \mathrm{mmol} / \mathrm{l}$ & $27.75 \mathrm{mmol} / 1$ & $27.75 \mathrm{mmol} / \mathrm{1}$ & $11.10 \mathrm{mmol} / 1$ \\
\hline Day 6 & $215 \pm 25^{a}$ & $700 \pm 40^{\mathrm{a}}$ & $565 \pm 28$ & $450 \pm 12$ \\
\hline Day 10 & $265 \pm 20$ & $165 \pm 44$ & $750 \pm 60$ & $710 \pm 20$ \\
\hline Day 12 & $220 \pm 50$ & $250 \pm 60$ & $125 \pm 12^{\mathrm{a}}$ & $755 \pm 50^{\mathrm{a}}$ \\
\hline
\end{tabular}

The insulin secretion $\left(\mu \mathrm{U} \cdot \mathrm{mg}\right.$ protein $\left.{ }^{-1} \cdot \mathrm{h}^{-1}\right)$ is expressed as mean \pm $\mathrm{SD}$ of six cultures. In experiment $\mathrm{A}$ the cultures were incubated with $11.10 \mathrm{mmol} / 1$ glucose for $2 \mathrm{~h}$, followed by $2 \mathrm{~h}$ in $27.75 \mathrm{mmol} / 1 \mathrm{glu}-$ cose, whilst in experiment $\mathrm{B}$ the glucose molarities were reversed. ${ }^{a} p<0.005$

Table 3. Extractable B cell insulin from islet cell monolayer cultures

\begin{tabular}{ll}
\hline Cultures & $\begin{array}{l}\mathrm{mU} \text { insulin/mg } \\
\text { cell protein }\end{array}$ \\
\hline Day 10 & $9.84 \pm 1.5$ \\
Day 12 & $1.85 \pm 1.0$ \\
Day 16 & $1.25 \pm 0.7$ \\
\hline
\end{tabular}

Results expressed as mean $\pm \mathrm{SD}$ of ten cultures

tures from five pancreases, $48-\mathrm{h}$ incubation in proline and serum-free complete Medium 199; cultures from seven pancreases, 48-h incubation in proline and serum-free complete Medium 199 containing cis-4-hydroxyproline; cultures from four pancreases, 48-h incubation in proline, valine and serum-free complete Me- dium 199 containing cis-4-hydroxyproline and D-valine. At the end of the incubation period, the medium was replaced with complete Medium 199 containing 5\% fetal calf serum. In cultures prepared from four pancreases, incubation with dispase was omitted and cultures were incubated in complete Medium 199, containing $5 \%$ fetal calf serum, porcine insulin $(5 \mu \mathrm{g} / \mathrm{ml})$ and putrescine $(0.2 \mathrm{mmol} / 1)$. No evidence of fibroblast outgrowth (determined by phase contrast microscopy) was found in cultures prepared in this manner. Normal morphological appearance and granulation of these cells was maintained up to 20 days in culture. Some morphological changes appeared after 25-30 days in culture, particularly degranulation. The granulation of B cells was monitored by phase contrast microscopy (Fig. 1) and aldehyde-fuchsin staining. Intense staining of granules was observed up to 20 days in culture, when a gradual loss of staining occurred. Light staining, but no evidence of granules was found in control fibroblast cultures. Three and 5-day old cultures were subjected to an indirect immunofluorescence assay, when rhodamine fluorescence was observed in the compact epitheliod cells, but control fibroblast cultures were negative.

Medium from the cultures was analyzed for the presence of insulin, glucagon and $\alpha$-amylase. After the first 10-12 days in culture, the B cells became unresponsive to the cycling of medium glucose concentrations (11.10-27.75 mmol/1) and insulin secretion decreased with increasing time in culture (Fig. 2). Glucagon secretion, measured on days 6,10 and 12 of culture in the presence of $11.10 \mathrm{mmol} / 1$ glucose, was $14.2 \pm 3.0$, $8.4 \pm 3.5$ and $9.0 \pm 2.8 \mathrm{ng} \cdot \mathrm{mg}$ protein ${ }^{-1} \cdot \mathrm{h}^{-1}$, respectively. No $\alpha$-amylase was found in media from 3 - and 5-day old cultures.

The ability of these cultures to synthesize DNA $\left({ }^{3} \mathrm{H}-\right.$ thymidine incorporation) was followed by autoradiography and the percentage of labelled cells was determined by counting 200 labelled cells in three separate fields (Table 1). The amount of glucose in the culture medium had no effect on the incorporation of ${ }^{3} \mathrm{H}$-thymidine into monolayer islet cell cultures on days 8 and 12 in culture (no statistically significant difference between values). However, these results indicate that during a 4-h incubation with ${ }^{3} \mathrm{H}$-thymidine, $39-46 \%$ of the cells in the culture were in S-phase and actively incorporating thymidine into nuclear DNA.

Response to short-term glucose stimulation was demonstrated by the cell monolayers. On days 6,10 and 12 in culture, cells were subjected to 2 -h incubations in serum-free medium (Table 2). One set of cultures was incubated with $11.10 \mathrm{mmol} / \mathrm{l}$ glucose for $2 \mathrm{~h}$, followed by $2 \mathrm{~h}$ in $27.75 \mathrm{mmol} / \mathrm{l}$ glucose. Another set of cultures was incubated with $27.75 \mathrm{mmol} / 1$ glucose followed by $11.10 \mathrm{mmol} / 1$ glucose. Day 6 cultured B cells responded normally to glucose stimulation, insulin secretion being stimulated by increased glucose concentrations. There was a significant difference between the amount of insulin secreted in response to 11.10 and $27.75 \mathrm{mmol} / 1$ 
glucose $(p<0.005)$. Day 10 cultured B cells, if challenged with $27.75 \mathrm{mmol} / 1$ glucose following $11.10 \mathrm{mmol} / 1$ glucose, did not increase insulin secretion. These cells responded to the initial $27.75 \mathrm{mmol} / 1$ glucose challenge by secreting high levels of insulin but only marginally reduced these levels when the glucose levels were decreased. Day 12 cultured B cells did not respond to the glucose challenge with increased insulin secretion, when the first $2-\mathrm{h}$ incubation was in $11.10 \mathrm{mmol} / 1$ glucose. These cultures exhibited a delayed response when $27.75 \mathrm{mmol} / 1$ glucose was in the initial incubation medium. An increased insulin secretion was found during the 2 -h incubation with $11.10 \mathrm{mmol} / 1$ glucose, but not during the initial 2-h incubation with $27.75 \mathrm{mmol} / 1$ glucose. However, there was a significant difference in the amount of insulin secreted during these two incubation periods $(p<0.005)$. This loss of responsiveness to glucose stimulation with length of time in culture is reflected in a corresponding decrease in the amount of extractable B cell insulin (Table 3). There is a significant difference $(p<0.001)$ between these latter values obtained from 10-day old cultures compared with those of 12- and 16-day old cultures.

\section{Discussion}

This study demonstrates that viable, glucose responsive pig pancreatic islet cells can be maintained in monolayer culture for 8-10 days. On day 8 in culture, islet cell monolayers secreted $850 \mu \mathrm{U}$ insulin/day (Fig. 2), which is in agreement with reported values for pig pseudo-islets (reaggregated trypsin isolated pancreatic islet cells) in culture, which on day 7 secreted $550 \mu \mathrm{U}$ insulin $/ 10^{6}$ cells [20]. These values are comparable with those observed from human fetal pancreas monolayers which secreted $1,350 \mu \mathrm{U} \cdot 35 \mathrm{~mm}^{2}$ culture ${ }^{-1} \cdot$ day $^{-1}$ on day 7 [21]. Although monolayers can be maintained for over 30 days, it is apparent that with lengthening time in culture beyond 12 days, cells begin to lose their functional capacity. This is expressed in the levels of insulin secretion in response to glucose stimulation and the amounts of insulin that could be extracted from the cells. It was found that the insulin secreted per culture declined after 12 days at $37^{\circ} \mathrm{C}$ although insulin could still be detected on day 34 . The cultures also showed changes in insulin secretion in response to a 2 -h glucose challenge with increasing time in culture. On day 6, a physiological response of increased insulin secretion to increased glucose concentration (2-h incubation with $27.75 \mathrm{mmol} / \mathrm{l}$ following $2 \mathrm{~h}$ with $11.10 \mathrm{mmol} / \mathrm{l}$ ) was seen but the response diminished by days 10 and 12 . When glucose $(27.75 \mathrm{mmol} / \mathrm{l})$ was present during the first $2-\mathrm{h}$ incubation, the cells did not reduce the levels of insulin secretion significantly during the second 2-h incubation with $11.10 \mathrm{mmol} / 1$ glucose. On day 12 , the response to the initial high glucose $(27.75 \mathrm{mmol} / \mathrm{l})$ did not appear until the second $2 \mathrm{~h}$ incubation with $11.10 \mathrm{mmol} / 1$ glucose.
Therefore, cells in long-term culture could not respond to glucose stimulation as rapidly as cells in vivo or in freshly isolated islet preparations [22]. This loss of physiological response to changes in glucose concentrations may be related to the culture conditions used, e. g., serum free medium $[23,24]$.

The observations that cells in monolayer cultures have the capacity to synthesize DNA suggest that cultured neonatal pig pancreatic cells have the capacity for growth after transplantation. The neonatal pancreas is much larger than the fetal pancreas and less fibrous than the adult pancreas. Therefore, it is relatively easy to obtain viable islets from this source. However, the yield is still rather low. Culture on a collagen substrate in enriched media appears to help maintain cells in good functional condition over the short term and also allows visualization of the homogeneity of the culture. While monolayer cultures may not be essential for preparing and storing islet cells for transplantation, they facilitate the removal of undesired cells and have a distinct advantage for morphological and biochemical studies.

Acknowledgements. This work was supported by a grant from the American Diabetes Association. The assistance of Dr. H. Schneider and J. Pyenson with the pancreatectomies is gratefully acknowledged.

\section{References}

1. Steffes MW, Sutherland DER, Mauer SM, Leonard RJ, Najarian JS, Brown DM (1975) Plasma insulin and glucose levels in diabetic rats prior to and following islet transplantation. J Lab Clin Med $85: 75-81$

2. Sutherland DER (1981) Pancreas and islet transplantation 1. Experimental studies. Diabetologia 20:161-185

3. Lacy PE, Davie JM, Finke EH (1979) Prolongation of islet allograft survival following in vitro culture $\left(24^{\circ} \mathrm{C}\right)$ and a single injection of ALS. Science 204: 312-313

4. Lacy PE, Davie JM, Finke EH (1981) Prolongation of islet xenograft survival (rat to mouse). Diabetes 30:285-291

5. Archer J, Kaye R, Mutter G (1980) Control of streptozotocin diabetes in Chinese hamsters by cultured mouse islet cells without immunosuppression: A preliminary report. J Surg Res 28: 77-85

6. Sutherland DER, Steffes MW, Bauer GE, McManus D, Najarian JS (1974) Isolation of human and porcine islets of Langerhans and islet transplantation in pigs. J Surg Res 16:102-111

7. Schrap DW, Murphy JJ, Newton WT, Ballinger WF, Lacy PE (1975) Transplantation of islets of Langerhans in diabetic rhesus monkeys. Surgery 77: 100-105

8. Mehigan-DG, Zuidema GD, Eggleston JC, Cameron JL (1980) Pancreatic islet autotransplantation. Results in dogs with chronic duct ligation. Am J Surg 139: 171-174

9. Sutherland DER (1981) Pancreas and islet transplantation II. Clinical trials. Diabetologia 20:435-450

10. Horaguchi A, Merrell RC (1981) Preparation of viable islet cells from dogs by a new method. Diabetes 30:455-458

11. Weber C, Strong D, Hirata R, Collins J, Light J, Nichols J, Press H, Gomez A, Wilkinson D, Budd R, Jones L, Reemtsma K (1980) New approaches to islet salvage: cryopreservation, culture, and perfusion of pancreatic fragments. Transplant Proc XII: 195-198

12. Gilbert SF, Migeon BR (1975) D-valine as a selective agent for normal human and rodent epithelial cells in culture. Cell 5:11-17

13. Kao WW-Y, Prockop DJ (1977) Proline analogue removes fibroblasts from cultured mixed cell populations. Nature 266: 63-64 
14. Hales CN, Randle PJ (1963) Immunoassay of insulin with insulin antibody precipitate. Biochem J 88: 137-146

15. Faloona GR, Unger RH (1974) Glucagon. In: Jaffe BM, Behrman HP (eds) Methods of radioimmunoassay. Academic Press, New York, pp 317-320

16. Ceska M, Brown B, Birath K (1969) Ranges of $\alpha$-amylase activities in human serum and urine and correlations with some other $\alpha$-amylase methods. Clin Chimica Acta 26: 445-453

17. Bussolati G, Bassa T (1974) Thiosulfation aldehyde fuchsin procedure for the staining of pancreatic B cells. Stain Tech 49:313-315

18. Orci L, Amherdt M, Baetens D, Malaisee-Lagae F, Ravazzola M, Rufner C (1977) Immunocytochemistry of pancreatic endocrine cells in vitro and in situ. In: Wasielewski $E$ von, Chick WL (eds) Pancreatic beta cell culture. Proceedings of 5th Workshop Conference Hoecht. Excerpta Medica, Amsterdam, pp 9-25

19. Peterson GL (1977) A simplification of the protein assay method of Lowry et al which is more generally applicable. Anal Biochem $83: 346-356$

20. Britt LD, Stojeba PC, Scharp CR, Greider MH, Scharp DW (1981) Neonatal pig pseudo-islets. A product of selective aggregation. Diabetes $30: 580-583$
21. Archer J, Kaye R (1981) Tissue culture of pig pancreas islet cells. Diabetes 30 (1): 136 (Abstract)

22. Ashby JP, Shirling D (1981) The priming effect of glucose on insulin secretion from isolated islets of Langerhans. Diabetologia 21: $230-234$

23. Anderson A (1978) Isolated mouse pancreatic islets in culture: Effects of serum and different culture media on the insulin production of the islets. Diabetologia 14: 397-404

24. Gylfe E (1978) Protection of pancreatic B cell glucoreceptor mechanism for insulin secretion during culture in chemically defined medium. Biochem J 174: 959-964

Received: 15 March 1982

and in revised form: 29 October 1982

Dr. F.J. Archer

Department of Pediatrics

Hahnemann Medical College \& Hospital

$230 \mathrm{~N}$ Broad Street

Philadelphia, PA 19102, USA 